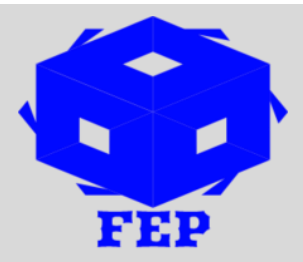

\title{
A REPORT ABOUT BENZOXAZINONE MATERIAL
}

\author{
Abdul Ahad ${ }^{1}$ \\ ${ }^{1}$ Department of Chemistry, University of Kabul, Afghanistan
}

*Corresponding Author: Abdul Ahad Article Received: 07-08-19
Accepted: 20-12-19
Published: $31-01-20$

Licensing Details: Author retains the right of this article. The article is distributed under the terms of the Creative Commons Attribution-Non Commercial 4.0 License (http://www.creativecommons.org/licences/by-nc/4.0/) which permits non-commercial use, reproduction and distribution of the work without further permission provided the original work is attributed as specified on the Journal open access page.

\section{ABSTRACT}

In this study, the objective was to investigate the Benzoxazinone material using the uncorrected and open capillary method for conducting and reporting the melting points. Laboratory grade and analytical grade reagents were used for conducting the synthesis and analytical studies based on with or without modification appropriately as and were required. Results showed that First of all the Synthesis of 2H-1, 4- benzoxazin-3(4H)-one was carried out by reacting 2- amino phenol with chloro acetyl chloride in dichloromethane in presence of triethylamine and then the bromo substitution was done by reacting with dibromoethane. Piperazine substituents were prepared in laboratory and then the title compounds were synthesized. One additional benzoyl substitution was also done. The entire synthesized compounds were primarily characterized by running T.L.C. and melting point analysis

Keywords: Benzoxazinone, Chemistry, Material, Open Capillary Method

\section{INTRODUCTION}

In the field of medicinal chemistry, compounds which consist of Benzoxazinone moieties are of huge significance due to their pharmacological characteristics. Benzoxazinone derivates combined with aromatic ring system and heterocyclic are found to be possessing different activities such as analgesic, anti-inflammatory, antifungal, and antimicrobial. The iosteric replacements of other rings for example oxaxolo and pyrido derivates are found to be producing antimicrobial activity. The Benzoxazinone are considered as important group of secondary metabolites occurring in Ranunculaceae, acanthaceae, and Gramineae. These compounds function as defense mechanism against pests such as insects and bacteria fungi. Novel 1, 4- Benzoxazinone 3-one derivate is synthesized which is reported to be inhibiting activities such as ABL, KDR, closely associated with chronic diseases such as cancer (Niemeyer, 1988; Zuing \& Massardo, 1991; Sonigara \& Ranawat, 2019). The structures of the newly synthesized compounds were elucidated through their IR, ${ }^{1} \mathrm{H}$ NMR, ${ }^{13} \mathrm{C}$ NMR and 
mass spectroscopic data. Once biological activity tests were performed on this newly created product, it showed promising behavior including antifungal and antibacterial activities.

\section{MATERIAL AND METHODS}

Uncorrected and open capillary method is used for conducting this study and reporting the melting points. Laboratory grade and analytical grade reagents were used for conducting the synthesis and analytical studies based on with or without modification appropriately as and were required. FTIR Bruker Tensor-27 model is used for the IR absorption spectra of the compounds. Elemental analysis and ${ }^{1} \mathrm{H}$ NMR spectroscopy is used for determining the constitution of the synthesized products supported by mass spectroscopy. The evaluation of the compounds is done using their vitro biological assay such as antibacterial activity towards Gram positive and Gram-negative bacterial strains and antifungal activity towards A. niger and C. albicans with different concentrations. Standard drugs were used for comparison basis for checking the biological activities of the synthesized compounds (Janez, Petra, Tefanic, Marija, \& Danijel, 2005).

\section{B. Synthesis of Phase I compounds 1. Synthesis of 4-\{2-[(2,4-dichlorophenyl)} amino]ethyl\}-2H-1,4-benzoxazin-3(4H)-one (B 1)

Based on stirred room temperature with 5 gram of sodium ethoxide, 5 grams of 2,4dichloroaniline, $20 \mathrm{ml}$ of ethanol, 5 grams of 2,40dicholoroaniline, 4 gram of sodium ethoxide is taken. The reaction mixture was refuxed for 3 hours on water bath. TLC was used for reaction monitoring. The resulting solution was cooled down, and poured into the ice-cold water of about $50 \mathrm{ml}$. The product precipitated out and was filtered, dried, and recrystallized from ethanol to provide solid compound.

Solubility: - Methanol

Solvent system: - chloroform: methanol (9.5:0.5)

2. Synthesis of 4-\{2-[(2-chlorophenyl) amino] ethyl\}-2H-1,4-benzoxazin-3(4H)-one (B 2) At stirred room temperature, 5 grams of sodium ethoxide, $5 \mathrm{ml}$ of 2-chloroaniline, 4benxoxazin-3(4H)-one, along with $1 \mathrm{gm}$ of 4-2-bromoethyl)-2H-1 is taken. The reaction mixture was refuxed for 3 hours on water bath. TLC is used for monitoring the reaction. Solution was cooled and poured in to the ice-cold water of about $50 \mathrm{ml}$. the product precipitated out and was filtered, dried, and recrystallized from ethanol to give solid compound.

Solubility: - Methanol

Solvent system: - chloroform: methanol (9.5:0.5)

3. Synthesis of 4-\{2-[(3-chlorophenyl) amino] ethyl $\}-2 H-1,4-b e n z o x a z i n-3(4 H)$-one (B 3) At stirred room temperature with 5 grams of sodium ethoxide, $5 \mathrm{ml}$ of 3-chloroanilineand, $20 \mathrm{ml}$ of ethanol, and $1 \mathrm{gm}$. 4-(2-bromoethyl)-2H-1, 4-benzoxazin-3(4H)-one was taken in round bottom flask. The reaction mixture was refuxed for 3 hours on water bath. TLC was used for monitoring the reaction. The solution was cooled, poured into ice cold water of about $50 \mathrm{ml}$. the product precipitated out and was filtered, dried, and recrystallized from ethanol to give solid compound.

Solubility: - Methanol 
Solvent system: - chloroform: methanol (9.5:0.5)

4. Synthesis of 4-\{2-[(4-chlorophenyl) amino]ethyl\}-2H-1,4-benzoxazin-3(4H)-one (B 4) Based on 5 gram of sodium ethoxide at room temperature, 5 grams of 4-chloroaniline, and $1 \mathrm{gm}$. 4-(2-bromoethyl)-2H-1, 4-benzoxazin-3(4H)-one was taken in a round bottom flask. The reaction mixture was refuxed for 3 hours on water bath. TLC was used for monitoring the reaction. The solution was cooled, poured into ice cold water of about $50 \mathrm{ml}$. the product precipitated out and was filtered, dried, and recrystallized from ethanol to give solid compound.

Solubility: - Methanol

Solvent system: - chloroform: methanol (9.5:0.5)

5. Synthesis of 4-\{2-[(3-methylphenyl) amino]ethyl\}-2H-1,4-benzoxazin-3(4H)-one (B 5) At stirred room temperature, 5 grams of sodium ethoxide is taken along with $5 \mathrm{ml}$ of 3methylaniline, and $1 \mathrm{gm}$. 4-(2-bromoethyl)-2H-1, 4-benzoxazin-3(4H)-one in round bottom flask. The reaction mixture was refuxed for 3 hours on water bath. TLC was used for monitoring the reaction. The solution was cooled, poured into ice cold water of about 50 $\mathrm{ml}$. the product precipitated out and was filtered, dried, and recrystallized from ethanol to give solid compound.

Solubility: - Methanol

Solvent system: - chloroform: methanol (9.5:0.5)

6. Synthesis of 4-\{2-[(2-methylphenyl) amino]ethyl\}-2H-1,4-benzoxazin-3(4H)-one (B 6) At stirred room temperature with 5 grams of sodium ethoxide, $5 \mathrm{ml}$ of 2-methylaniline (otoluidine) is taken along with $1 \mathrm{gm}$. 4-(2-bromoethyl)-2H-1, 4-benzoxazin-3(4H)-one in a round bottom flask. The reaction mixture was refuxed for 3 hours on water bath. TLC was used for monitoring the reaction. The solution was cooled, poured into ice cold water of about $50 \mathrm{ml}$. the product precipitated out and was filtered, dried, and recrystallized from ethanol to give solid compound. Solubility: - Methanol

Solvent system: - chloroform: methanol (9.5:0.5)

7. Synthesis of 4-\{2-[(4-methylphenyl) amino] ethyl\}-2H-1,4-benzoxazin-3(4H)-one (B 7) At stirred room temperature with 5 grams of sodium ethoxide, 5 grams of 4-methylaniline (p-toluidine) is taken along with $1 \mathrm{gm}$. 4-(2-bromoethyl)-2H-1, 4-benzoxazin-3(4H)-one in a round bottom flask.

$1 \mathrm{gm}$. 4-(2-bromoethyl)-2H-1, 4-benzoxazin-3(4H)-one was taken in a round bottom flask with $20 \mathrm{ml}$ of ethanol, 5 grams of 4-methylaniline (p-toluidine) and stirred at room temperature with 5 grams of sodium ethoxide. Then the reaction mixture was refluxed for $3 \mathrm{hrs}$ on water bath. The reaction was monitored by TLC for completion. The solution was cooled, poured into ice cold water $(50 \mathrm{ml})$. The product precipitated out and was filtered, dried and recrystallized from ethanol to give solid compound.

Solubility: - Methanol

Solvent system: - chloroform: methanol (9.5:0.5) 
8. Synthesis of 4-\{2-[(3,5-dimethylphenyl) amino]ethyl\}-2H-1,4-benzoxazin-3(4H)-one (B 8)

At stirred room temperature with 5 grams of sodium ethoxide, $5 \mathrm{ml}$ of 3,5-dimethylaniline, $1 \mathrm{gm}$. 4-(2-bromoethyl)-2H-1, 4-benzoxazin-3(4H)-one is taken in a round bottom flask.

$1 \mathrm{gm}$. 4-(2-bromoethyl)-2H-1, 4-benzoxazin-3(4H)-one was taken in a round bottom flask with $20 \mathrm{ml}$ of ethanol, $5 \mathrm{ml}$ of 3,5-dimethylaniline (3,5-xylidine) and stirred at room temperature with 5 grams of sodium ethoxide. Then the reaction mixture was refluxed for $3 \mathrm{hrs}$ on water bath. The reaction was monitored by TLC for completion. The solution was cooled, poured into ice cold water $(50 \mathrm{ml})$. The product precipitated out and was filtered, dried and recrystallized from ethanol to give solid compound.

Solubility: - Methanol

Solvent system: - chloroform: methanol (9.5:0.5)

9. Synthesis of 4-\{2-[(2-nitrophenyl) amino]ethyl\}-2H-1,4-benzoxazin-3(4H)-one (B 9)

At stirred room temperature with 5 grams of sodium ethoxide, 5 grams of 2-nitroanilineand is taken along with $1 \mathrm{gm}$. 4-(2-bromoethyl)-2H-1, 4-benzoxazin-3(4H)-one in a round bottom flask.

Then the reaction mixture was refluxed for $3 \mathrm{hrs}$ on water bath. The reaction was monitored by TLC for completion. The solution was cooled, poured into ice cold water $(50 \mathrm{ml})$. The product precipitated out and was filtered, dried and recrystallized from ethanol to give solid compound.

Solubility: - Methanol

Solvent system: - chloroform: methanol (9.5:0.5)

10. Synthesis of 4-\{2-[(3-nitrophenyl) amino] ethyl\}-2H-1,4-benzoxazin-3(4H)-one (B 10) At stirred room temperature with 5 grams of sodium ethoxide, 5 grams of 3-nitroanilineand is taken along with the $1 \mathrm{gm}$. 4-(2-bromoethyl)-2H-1, 4-benzoxazin-3(4H)-one in a round bottom flask. Then the reaction mixture was refluxed for 3 hrs on water bath. The reaction was monitored by TLC for completion. The solution was cooled, poured into ice cold water $(50 \mathrm{ml})$. The product precipitated out and was filtered, dried and recrystallized from ethanol to give solid compound.

Solubility: - Methanol

Solvent system: - chloroform: methanol (9.5:0.5)

11. Synthesis of 4-\{2-[(4-nitrophenyl) amino]ethyl\}-2H-1,4-benzoxazin-3(4H)-one (B 11) At stirred room temperature, 5 grams of sodium ethoxide, 5 gram of 4-nitroanilineand is taken along with $1 \mathrm{gm}$. 4-(2-bromoethyl)-2H-1, 4-benzoxazin-3(4H)-one in a round bottom flask. Then the reaction mixture was refluxed for $3 \mathrm{hrs}$ on water bath. The reaction was monitored by TLC for completion. The solution was cooled, poured into ice cold water $(50 \mathrm{ml})$. The product precipitated out and was filtered, dried and recrystallized from ethanol to give solid compound.

Solubility: - Methanol

Solvent system: - chloroform: methanol (9.5:0.5) 
12. Synthesis of 4-\{2-[(2-bromophenyl) amino]ethyl $\}-2 H-1,4-b e n z o x a z i n-3(4 H)$-one (B 12)

At stirred room temperature, 5 grams of sodium ethoxide, $5 \mathrm{ml}$ of 2-bromoanilineand is taken along with $1 \mathrm{gm}$. 4-(2-bromoethyl)-2H-1, 4-benzoxazin-3(4H)-one in a round bottom flask. Then the reaction mixture was refluxed for $3 \mathrm{hrs}$ on water bath. The reaction was monitored by TLC for completion. The solution was cooled, poured into ice cold water $(50 \mathrm{ml})$. The product precipitated out and was filtered, dried and recrystallized from ethanol to give solid compound.

Solubility: - Methanol

Solvent system: - chloroform: methanol (9.5:0.5)

13. Synthesis of 4-\{2-[(4-bromophenyl) amino]ethyl\}-2H-1,4-benzoxazin-3(4H)-one (B 13)

At stirred room temperature, 5 grams of sodium ethoxide along with 5 grams of 4bromoanilineand stirred is taken along with the 1 gm. 4-(2-bromoethyl)-2 $\mathrm{H}-1$, 4benzoxazin-3 $(4 H)$-one in round bottom flask. Then the reaction mixture was refluxed for 3 hrs on water bath. The reaction was monitored by TLC for completion. The solution was cooled, poured into ice cold water $(50 \mathrm{ml})$. The product precipitated out and was filtered, dried and recrystallized from ethanol to give solid compound.

Solubility: - Methanol

Solvent system: - chloroform: methanol (9.5:0.5)

14. Synthesis of 4-\{2-[(2,4,6-tribromophenyl) amino]ethyl $\}-2 H-1,4-b e n z o x a z i n-3(4 H)$ one (B 14)

At stirred room temperature, 5 grams of sodium ethoxide, 5 grams of 2,4,6tribromoanilineand is taken along with $1 \mathrm{gm}$. 4-(2-bromoethyl)-2H-1, 4-benzoxazin-3(4H)one in a round bottom flask. Then the reaction mixture was refluxed for $3 \mathrm{hrs}$ on water bath. The reaction was monitored by TLC for completion. The solution was cooled, poured into ice cold water $(50 \mathrm{ml})$. The product precipitated out and was filtered, dried and recrystallized from ethanol to give solid compound.

Solubility: - Methanol

Solvent system: - chloroform: methanol (9.5:0.5)

15. Synthesis of 4-\{2-[(4-methoxyphenyl) amino]ethyl\}-2H-1,4-benzoxazin-3(4H)-one (B 15)

At stirred room temperature, 5 grams of sodium ethoxide, 5 grams of 4-methoxyaniline (pAnisidine) is taken along with $1 \mathrm{gm}$. 4-(2-bromoethyl)-2H-1, 4-benzoxazin-3(4H)-one in a round bottom flask. Then the reaction mixture was refluxed for $3 \mathrm{hrs}$ on water bath. The reaction was monitored by TLC for completion. The solution was cooled, poured into ice cold water $(50 \mathrm{ml})$. The product precipitated out and was filtered, dried and recrystallized from ethanol to give solid compound.

Solubility: - Methanol

Solvent system: - chloroform: methanol (9.5:0.5) 
16. Synthesis of 4-\{2-[(2-methoxyphenyl) amino]ethyl $\}-2 H$-1,4-benzoxazin-3(4H)-one (B 16)

At stirred room temperature, 5 grams of sodium ethoxide, $5 \mathrm{ml}$ of 2-methoxyaniline (oAnisidine), is taken along with $1 \mathrm{gm}$. 4-(2-bromoethyl)-2H-1, 4-benzoxazin-3(4H)-one in a round bottom flask. Then the reaction mixture was refluxed for $3 \mathrm{hrs}$ on water bath. The reaction was monitored by TLC for completion. The solution was cooled, poured into ice cold water $(50 \mathrm{ml})$. The product precipitated out and was filtered, dried and recrystallized from ethanol to give solid compound.

Solubility: - Methanol

Solvent system: - chloroform: methanol (9.5:0.5)

17. Synthesis of 4-[2-(propan-2-ylamino) ethyl]-2H-1,4-benzoxazin-3(4H)-one (B 17)

At stirred room temperature, 5 grams of sodium ethoxide, $5 \mathrm{ml}$ of $\mathrm{N}$ methylmethanamineand is taken along with $1 \mathrm{gm}$. 4-(2-bromoethyl)-2H-1, 4-benzoxazin$3(4 H)$-one in a round bottom flask. Then the reaction mixture was refluxed for $3 \mathrm{hrs}$ on water bath. The reaction was monitored by TLC for completion. The solution was cooled, poured into ice cold water $(50 \mathrm{ml})$. The product precipitated out and was filtered, dried and recrystallized from ethanol to give solid compound.

Solubility: - Methanol

Solvent system: - chloroform: methanol (9.5:0.5)

18. Synthesis of 4-[2-(pentan-3-ylamino) ethyl]-2H-1,4-benzoxazin-3(4H)-one (B 18)

At stirred room temperature, 5 grams of sodium ethoxide, $5 \mathrm{ml}$ of N-ethylethanamine (Diethylamine) is taken along with $1 \mathrm{gm}$. 4-(2-bromoethyl)-2H-1, 4-benzoxazin-3(4H)-one in a round bottom flask. Then the reaction mixture was refluxed for $3 \mathrm{hrs}$ on water bath. The reaction was monitored by TLC for completion. The solution was cooled, poured into ice cold water $(50 \mathrm{ml})$. The product precipitated out and was filtered, dried and recrystallized from ethanol to give solid compound.

Solubility: - Methanol

Solvent system: - chloroform: methanol (9.5:0.5)

19. Synthesis of 4-[2-(diphenylamino) ethyl]-2H-1,4-benzoxazin-3(4H)-one (B 19)

At stirred room temperature, 5 grams of sodium ethoxide, 5 grams of $\mathrm{N}$-phenylaniline (Diphenylamine) is taken along with $1 \mathrm{gm}$. 4-(2-bromoethyl)-2 $\mathrm{H}$-1, 4-benzoxazin-3(4H)one in a round bottom flask. Then the reaction mixture was refluxed for $3 \mathrm{hrs}$ on water bath. The reaction was monitored by TLC for completion. The solution was cooled, poured into ice cold water $(50 \mathrm{ml})$. The product precipitated out and was filtered, dried and recrystallized from ethanol to give solid compound.

Solubility: - Methanol

Solvent system: - chloroform: methanol (9.5:0.5)

20. Synthesis of 4-[2-(morpholin-4-yl)ethyl]-2H-1,4-benzoxazin-3(4H)-one (B 20)

At stirred room temperature, 5 grams of sodium ethoxide, $5 \mathrm{ml}$ of morpholineand is taken along with $1 \mathrm{gm}$. 4-(2-bromoethyl)-2H-1, 4-benzoxazin-3(4H)-one in a round bottom flask. Then the reaction mixture was refluxed for $3 \mathrm{hrs}$ on water bath. The reaction was monitored by TLC for completion. The solution was cooled, poured into ice cold water $(50 \mathrm{ml})$. The 
product precipitated out and was filtered, dried and recrystallized from ethanol to give solid compound.

Solubility: - Methanol

Solvent system: - chloroform: methanol (9.5:0.5)

\section{Synthesis of 4-[2-(piperazin-1-yl)ethyl]-2H-1,4-benzoxazin-3(4H)-one (B 21)}

At stirred room temperature, 50 grams of sodium ethoxide is taken along with the $10 \mathrm{gm}$. 4(2-bromoethyl)-2H-1, 4-benzoxazin-3(4H)-one in a round bottom flask. Then the reaction mixture was refluxed for $3 \mathrm{hrs}$ on water bath. The reaction was monitored by TLC for completion. The solution was cooled, poured into ice cold water $(50 \mathrm{ml})$. The product precipitated out and was filtered, dried and recrystallized from ethanol to give solid compound.

Solubility: - Methanol

Solvent system: - chloroform: methanol (9.5:0.5)

22. Synthesis of 4-[2-(piperidin-1-yl) ethyl]-2H-1,4-benzoxazin-3(4H)-one (B 22)

At stirred room temperature, 5 grams of sodium ethoxide, $5 \mathrm{ml}$ of piperidineand is taken along with $1 \mathrm{gm}$. 4-(2-bromoethyl)-2H-1, 4-benzoxazin-3(4H)-one in a round bottom flask. Then the reaction mixture was refluxed for $3 \mathrm{hrs}$ on water bath. The reaction was monitored by TLC for completion. The solution was cooled, poured into ice cold water $(50 \mathrm{ml})$. The product precipitated out and was filtered, dried and recrystallized from ethanol to give solid compound.

Solubility: - Methanol

Solvent system: - chloroform: methanol (9.5:0.5)

23. Synthesis of 4-[2-(2-methylpiperazin-1-yl) ethyl]-2H-1,4-benzoxazin-3(4H)-one (B 23)

At stirred room temperature, 5 grams of sodium ethoxide, $5 \mathrm{ml}$ of 2-methylpiperazineand is taken along with $1 \mathrm{gm}$. 4-(2-bromoethyl)-2H-1, 4-benzoxazin-3(4H)-one in a round bottom flask. Then the reaction mixture was refluxed for $3 \mathrm{hrs}$ on water bath. The reaction was monitored by TLC for completion. The solution was cooled, poured into ice cold water $(50 \mathrm{ml})$. The product precipitated out and was filtered, dried and recrystallized from ethanol to give solid compound.

Solubility: - Methanol

Solvent system: - chloroform: methanol (9.5:0.5)

\section{Synthesis of Phase II compounds 1. Synthesis of 4-\{2-[4-(4-aminophenyl) piperazin-1- yl] ethyl -2H-1,4-benzoxazin-3(4H)-one (C 1)}

We took $1 \mathrm{~g}$ of 4-[2-(piperazin-1-yl) ethyl]-2H-1, 4-benzoxazin-3(4H)-one in round bottom flask and dissolved in $3 \mathrm{~g}$ of Potassium iodide, $5 \mathrm{ml}$ 4-chloro aniline, and $15 \mathrm{ml}$ of $15 \%$ Sodium Hydroxide solution which was stirred well and few $\mathrm{ml}$ of HCI was added and refluxed for 3 hours. The hot mixture was poured in ice cold water and the precipitate of the respective substitute was obtained and was recrystallized with the ethanol. TLC was used for monitoring the reaction.

Solubility: - dimethylformamide 
Solvent system: - chloroform: methanol (9.5:0.5)

2. Synthesis of 4-\{4-[2-(3-oxo-2,3-dihydro-4H-1,4-benzoxazin-4-yl) ethyl]piperazin-1yl\}benzaldehyde (C 2)

$1 \mathrm{~g}$ of 4-[2-(piperazin-1-yl) ethyl]-2H-1, 4-benzoxazin-3(4H)-one was taken in a round bottom flask and dissolved with $3 \mathrm{~g}$ of Potassium iodide, $5 \mathrm{ml}$ 4-Chloro benzaldehyde, and $15 \%$ Sodium Hydroxide solution which was stirred well and few $\mathrm{ml}$ of HCI was added and refluxed for 3 hours. This hot mixture was poured in ice cold water and the precipitate of the respective substitute was obtained and was recrystallized with the ethanol. TLC was used for monitoring the reaction.

Solubility: - dimethylformamide

Solvent system: - chloroform: methanol (9.5:0.5)

3. Synthesis of 4-[2-(4-phenylpiperazin-1-yl) ethyl]-2H-1,4-benzoxazin-3(4H)-one (C 3) $1 \mathrm{~g}$ of 4-[2-(piperazin-1-yl) ethyl]-2H-1, 4-benzoxazin-3(4H)-one was taken in a round bottom flask and dissolved in $3 \mathrm{~g}$ of Potassium iodide, few $\mathrm{ml}$ of HCI, $5 \mathrm{ml}$ Chloro benzene and $15 \%$ Sodium Hydroxide solution which was well stirred and refluxed for 3 hours. This hot mixture was poured in ice cold water and the precipitate of the respective substitute was obtained and recrystallized with the ethanol. TLC was used for monitoring the complete reaction.

Solubility: - dimethylformamide

Solvent system: - chloroform: methanol (9.5:0.5)

4. Synthesis of 2-\{4-[2-(3-oxo-2,3-dihydro-4H-1,4-benzoxazin-4-yl) ethyl]piperazin-1yl\}benzoic acid (C 4)

$1 \mathrm{~g}$ of 4-[2-(piperazin-1-yl) ethyl]-2H-1, 4-benzoxazin-3(4H)-one was taken in a round bottom flask and dissolved with $3 \mathrm{~g}$ of Potassium iodide, 5 grams 2-chloro benzoic acid, and $15 \mathrm{ml}$ of $15 \%$ Sodium Hydroxide solution. This hot mixture was poured in the ice cold water and the precipitate of the respective substitute was obtained and recrystallized with the ethanol. TLC was used for monitoring the reaction.

Solubility: - dimethylformamide

Solvent system: - chloroform: methanol (9.5:0.5)

5. Synthesis of 4-\{2-[4-(2-aminophenyl) piperazin-1-yl] ethyl $\}-2 H$-1,4-benzoxazin-3(4H)one (C 5)

$1 \mathrm{~g}$ of 4-[2-(piperazin-1-yl) ethyl]-2H-1, 4-benzoxazin-3(4H)-one was taken in a round bottom flask and mixed with HCI, $3 \mathrm{~g}$ of Potassium iodide, and $5 \mathrm{ml}$ 2-Chloro aniline. This hot mixture was poured in ice cold water and the precipitate of the respective substitute was obtained and was recrystallized with the ethanol. TLC was used for monitoring the complete reaction.

Solubility: - dimethylformamide

Solvent system: - chloroform: methanol (9.5:0.5)

6. Synthesis of 44-[2-(3-oxo-2,3-dihydro-4H-1,4-benzoxazin-4-yl) ethyl]piperazin1-yl\}acetic acid (C 6)

$1 \mathrm{~g}$ of 4-[2-(piperazin-1-yl) ethyl]-2H-1, 4-benzoxazin-3(4H)-one was taken in a round bottom flask and added with few $\mathrm{ml}$ of HCI, $3 \mathrm{~g}$ of Potassium iodide, 5 grams of Chloro 
acetic acid, and $15 \%$ Sodium Hydroxide solution which was refluxed for 3 hours. The hot mixture was poured in ice cold water and the precipitate of the respective substitute was obtained and was recrystallized with the ethanol. TLC was used for monitoring the complete reaction.

Solubility: - dimethylformamide

Solvent system: - chloroform: methanol (9.5:0.5)
7. Synthesis
of
4-\{4-[2-(3-oxo-2,3-dihydro-4H-1,4-benzoxazin-4-

yl)ethyl]piperazin-1-yl\}benzoic acid (C 7) 1 g of 4-[2-(piperazin-1-yl) ethyl]-2H-1, 4benzoxazin-3(4H)-one was taken in a round bottom flask and $3 \mathrm{~g}$ of Potassium iodide along with few $\mathrm{ml}$ of HCI, 5 grams 4-Chlorobenzoic acid, and $15 \mathrm{ml}$ of 15\% Sodium Hydroxide solution which was refluxed for 3 hours. This hot mixture was poured in ice cold water and the precipitate of the respective substitute was obtained was recrystallized with the ethanol.

TLC was used for monitoring the complete process.

Solubility: - dimethylformamide

Solvent system: - chloroform: methanol (9.5:0.5)

Table 1: Antibacterial Activity of Synthesized Compounds (mean of Zone of Inhibition)

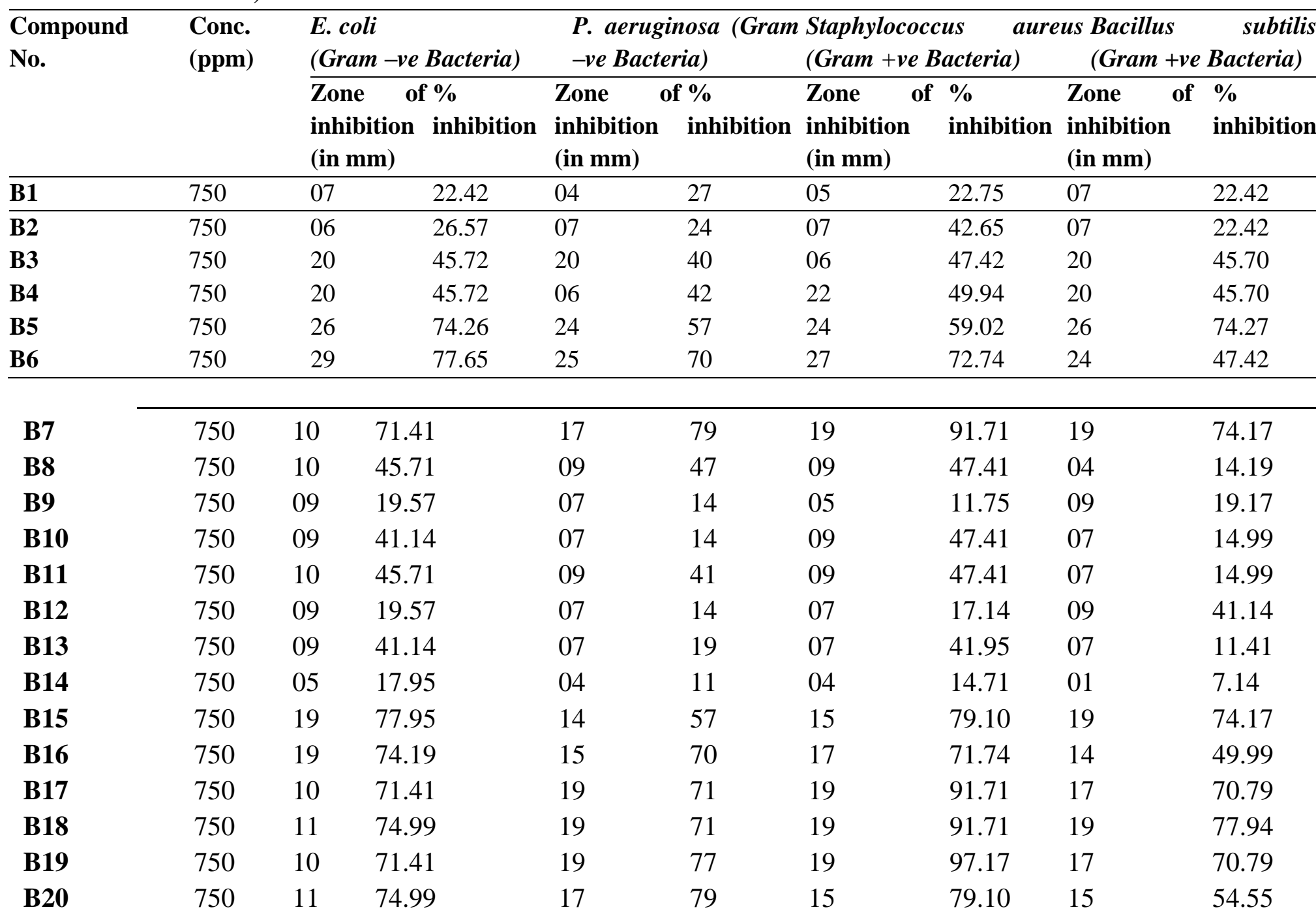




$\begin{array}{llllllllll}\text { B21 } & 750 & 24 & 92.14 & 20 & 90 & 16 & 66.19 & 19 & 66.94 \\ \text { B22 } & 750 & 22 & 69.56 & 19 & 66 & 19 & 91.62 & 19 & 66.94 \\ \text { B23 } & 750 & 24 & 95.61 & 21 & 94 & 19 & 96.26 & 19 & 64.26 \\ \text { C1 } & 750 & 26 & 92.95 & 21 & 94 & 20 & 90.90 & 19 & 66.94 \\ \text { C2 } & 750 & 24 & 95.61 & 20 & 90 & 20 & 90.90 & 20 & 61.40 \\ \text { C3 } & 750 & 22 & 69.56 & 19 & 62 & 16 & 62.64 & 19 & 64.26 \\ \text { C4 } & 750 & 24 & 92.14 & 19 & 66 & 16 & 62.64 & 16 & 60.69 \\ \text { C5 } & 750 & 24 & 95.61 & 20 & 90 & 19 & 91.62 & 19 & 66.94 \\ \text { C6 } & 750 & 25 & 99.29 & 22 & 99 & 20 & 90.90 & 19 & 64.26 \\ \text { C7 } & 750 & 24 & 95.61 & 21 & 94 & 21 & 95.44 & 19 & 66.94 \\ \text { Standard- I } & \mathbf{7 5 0} & \mathbf{2 8} & \mathbf{1 0 0} & \mathbf{2 5} & \mathbf{1 0 0} & \mathbf{2 2} & \mathbf{1 0 0} & \mathbf{2 8} & \mathbf{1 0 0} \\ \text { (ciprofloxacin) } & & & & & & & & & \end{array}$

Table 2: Antifungal Activity of Synthesized Compounds

\begin{tabular}{|c|c|c|c|c|c|}
\hline \multirow{3}{*}{$\begin{array}{l}\text { Compound } \\
\text { No. }\end{array}$} & \multirow{3}{*}{$\begin{array}{l}\text { Conc. } \\
\text { (ppm) }\end{array}$} & \multirow{2}{*}{\multicolumn{2}{|c|}{$\begin{array}{l}\text { C. albicans } \\
\text { Zone of inhibition (in \% }\end{array}$}} & \multicolumn{2}{|c|}{ A. niger } \\
\hline & & & & $\underline{\text { Zone }}$ & $\%$ \\
\hline & & mm) & inhibition & $\underline{\mathbf{m m}}$ & inhibition \\
\hline B1 & 750 & 04 & 31.04 & 04 & 33.30 \\
\hline B2 & 750 & 06 & 31.66 & 06 & 38.86 \\
\hline B3 & 750 & 08 & 36.93 & 06 & 33.30 \\
\hline B4 & 750 & 06 & 31.66 & 04 & 33.30 \\
\hline B5 & 750 & 14 & 83.64 & 11 & 61.06 \\
\hline B6 & 750 & 13 & 63.13 & 14 & 88.80 \\
\hline B7 & 750 & 16 & 89.90 & 14 & 88.80 \\
\hline B8 & 750 & 09 & 43.09 & 06 & 33.30 \\
\hline B9 & 750 & 04 & 31.04 & 06 & 38.86 \\
\hline B10 & 750 & 04 & 31.04 & 06 & 33.30 \\
\hline B11 & 750 & 11 & 68.96 & 09 & 49.96 \\
\hline B12 & 750 & 06 & 31.66 & 04 & 33.30 \\
\hline B13 & 750 & 06 & 36.30 & 06 & 33.30 \\
\hline B14 & 750 & 03 & 10.63 & 03 & 11.10 \\
\hline B15 & 750 & 10 & 63.60 & 11 & 61.06 \\
\hline B16 & 750 & 14 & 83.64 & 13 & 83.16 \\
\hline B17 & 750 & 16 & 94.16 & 13 & 83.16 \\
\hline B18 & 750 & 16 & 94.16 & 16 & 93.36 \\
\hline B19 & 750 & 18 & 99.43 & 16 & 99.90 \\
\hline B20 & 750 & 18 & 99.43 & 16 & 93.36 \\
\hline B21 & 750 & 19 & 94.69 & 14 & 88.80 \\
\hline B22 & 750 & 19 & 94.69 & 16 & 99.90 \\
\hline B23 & 750 & 14 & 83.64 & 16 & 93.36 \\
\hline C1 & 750 & 19 & 94.69 & 16 & 93.36 \\
\hline
\end{tabular}




\begin{tabular}{|c|c|c|c|c|c|}
\hline $\mathrm{C} 2$ & 750 & 16 & 94.16 & 16 & 93.36 \\
\hline $\mathbf{C 3}$ & 750 & 16 & 93.16 & 19 & 93.36 \\
\hline $\mathrm{C} 4$ & 750 & 16 & 99.90 & 16 & 99.90 \\
\hline C5 & 750 & 19 & 99.32 & 16 & 99.90 \\
\hline C6 & 750 & 13 & 93.63 & 13 & 99.90 \\
\hline C7 & 750 & 16 & 93.16 & 16 & 93.26 \\
\hline $\begin{array}{l}\text { Standard- } \\
\text { (Griseofulvi }\end{array}$ & $\begin{array}{l}\text { I750 } \\
\text { n) }\end{array}$ & 19 & 100 & 18 & 100 \\
\hline
\end{tabular}

Table 3: Minimum Inhibitory Concentration (MIC) of the Most Potent Compounds

\begin{tabular}{|c|c|c|c|c|c|}
\hline \multirow{2}{*}{$\begin{array}{l}\text { Compound } \\
\text { No. }\end{array}$} & \multicolumn{5}{|c|}{$\operatorname{MIC}(\mu \mathrm{g} / \mathrm{mL})$} \\
\hline & E. coli & P. aeruginosa & Stal & s Bacillus & tilis \\
\hline & \multicolumn{4}{|c|}{$($ Gram-ve Bacteria) $($ Gram-ve Bacteria) (Gram +ve Bacteria) (Gram } & $+v e$ \\
\hline \multicolumn{6}{|c|}{ Bacteria) } \\
\hline B19 & 60 & 70 & 6 & 65 & \\
\hline B21 & 65 & 65 & 6. & 65 & \\
\hline C1 & 65 & 65 & 6 & 65 & \\
\hline $\mathbf{C 2}$ & 60 & 65 & 6 & 65 & \\
\hline C4 & 65 & 65 & 6 & 40 & \\
\hline C5 & 65 & 60 & 4 & 65 & \\
\hline C6 & 65 & 65 & 6 & 65 & \\
\hline C7 & 65 & 65 & 6 & 65 & \\
\hline
\end{tabular}

\section{RESULT AND DISCUSSION}

Benzoxazinones is an important class group of secondary metabolites occurring in Scrophulariaceae, Ranunculaceae, Acanthaceae, and Gramineae. They are reported to be performing good function of antibacterial and angifungal in different cereals including rye and corn wheat. The study of Benzoxazinone is old and well-recorded in chemistry field. The compounds encompassing Benzoxazinone moiety are highly significant and used in agriculture and pharmaceutical industry. Hetrocycles bearing Benzoxazinone ring residue are reported to be showing good progress in terms of acting as CNS depressant, antioxidant, antiviral, antimalerial, anticonvulsant, analgesic, and anti-inflammatory. In addition, benzoxazinone forms an important pharmacaphore in fungicidal, herbicidal and insecticidal, agents. Novel 1,4-benzoxazinone-3-one derivative has been synthesized which would have inhibitory activities against tyrosine kinases and the inhibitory activities against KDR and ABL which are closely related to chronic disease such as cancer. 1,4benzoxazinone has wide application in medicinal chemistry due to its pharmacological properties. The members of this family are used for treating antidepressants, potassium channel openers, reperfusion, and Parkinson's disease, Moreover, 1,4-benzoxazinone used as intermediates for the synthesis of aza sugar. First of all the Synthesis of $2 \mathrm{H}-1$, 4- 
benzoxazin-3(4H)-one was carried out by reacting 2- amino phenol with chloro acetyl chloride in dichloromethane in presence of triethylamine and then the bromo substitution was done by reacting with dibromoethane. Piperazine substituents were prepared in laboratory and then the title compounds were synthesized. One additional benzoyl substitution was also done. The entire synthesized compounds were primarily characterized by running T.L.C. and melting point analysis.

\section{References}

Janez, I., Petra, S., Tefanic, A., Marija, S.D., \& Danijel, K. (2005). Recent advances in the synthesis of $2 H$-1,4benzoxazin-3-(4H)-ones and 3,4-dihydro-2H-1,4-benzoxazines. Tetrahedron, 61, 7325-7348.

Kumar, P., Donald, M., \& Milliam, S.C. (1994). 2H-1,4-benzoxazjn-3(4H)-one, An intermediate in the biosynthesis of cyclic Hydroxamic acids in Maize. Phymhemistry, 36(4), 893498.

Moussavi, Z., Plancke, M,O., Olivier, P., Lesieur, D., Fruchart, J.C., and Sauzieres, J. (1989). Lipid lowering actions of 7-( 2-methylene butyryl) - (2H) -1,4-benzoxazin3-( $4 H)$-one derivatives in mice, rats and Syrian hamsters. ClinicaChimicaActa, $180,35-44$.

Niemeyer, H.M. (1988). Hydroxamic acids (4-hydroxy-14-benzoxazin-3-ones) defense chemicals in the gramineae. Phytochemistry, 27, 3349-3358.

Piao, Z.T., Guan, L.P., Zhao, L.M., Hu, R.P., Quan, Z.S. (2008). Synthesis of novel 7benzylamino-2H-1,4-benzoxazin3(4H)-ones as anticonvulsant agents. European Journal of Medicinal Chemistry, 43, 1216-1221.

Seckin, O., Aydin, M.O., Hakan, G., Nurten, A. (2000). Synthesis and antimicrobial activity of some new 4-hydroxy2H-1,4-benzoxazin-3(4H)-ones Il. Farmaco, 55, 715-718.

Sonigara, B.S., Ranawat, M.S. (2019). Synthesis and Screening of some benzoxazinone derivatives. Journal of Drug Delivery and Therapeutics, 9(4-s), 974-977. http://dx.doi.org/10.22270/jddt.v9i4-s.3699www.arkatusa.com

Tripathi, K.D. (2003). Essential of medical pharmacology (5 ${ }^{\text {th }}$ ed.). New Delhi (India): Jaypee brothers medical publishers.

Williams, D.A., \& Lemke, T.L. (2002). Foye's principles of medicinal chemistry $\left(5^{\text {th }} \mathrm{ed}\right.$.) Philadelphia (USA): Lippincott Williams and Wilkins.

Zunig, G.E., Massardo, F. (1991). Hydroxamic acid content in undifferentiated and differentiated tissues of wheat. Phytochemistry, 30, 3281-3283. 